УДК 378.33

DOI https://doi.org/10.32782/apv/2021.4.7

\title{
Надія ГАЛЮК
}

кандидат медичних наук, доиент, Івано-Франківський національний медичний університет, вул. Галицька, 2, м. Івано-Франківськ, Україна, 76000

ORCID: 0000-0003-2026-0937

\section{Тетяна ДІВНИЧ}

кандидат медичних наук, доиент, Івано-Франківський національний медичний університет, вул. Галищька, 2, м. Івано-Франківськ, Украӥна, 76000

ORCID: 0000-0003-2549-867X

\section{Наталія НИЩУК}

асистент, Івано-Франківський національний медичний університет, вул. Галищька, 2, м. Івано-Франківськ, Україна, 76000

ORCID: 0000-0002-4338-6121

\section{Наталя ТИМОЧКО}

кандидат медичних наук, доцент, Івано-Франківський національний медичний університет, вул. Галицька, 2, м. Івано-Франківськ, Украӥна, 76000

ORCID: 0000-0002-5319-5468

Бібліографічний опис статті: Галюк, Н., Дівнич, Т., Нищук, Н., Тимочко, Н. (2021). Метод проєктів як засіб розвитку пізнавальних інтересів здобувачів освіти. Acta Paedagogica Volynienses, 4, 39-44, doi: https://doi.org/10.32782/apv/2021.4.7

\section{МЕТОД ПРОЕКТІВ ЯК ЗАСІБ РОЗВИТКУ ПІЗНАВАЛЬНИХ ІНТЕРЕСІВ ЗДОБУВАЧІВ ОСВІТИ}

У статті наголошується, щุо провідним завданням сучасного закладу вищої освіти є підготовка всебічно розвиненої особистості, з якісною освітою, з добре сформованими професійними компетентностями, яка володіє знаннями, високими моральними якостями й здатна самостійно діяти в різноманітних життєвих ситуаціях, застосовуючи свої знання, досвід і беручи на себе відповідальність за результати прийнятих рішень та власну медичну практику. Мета статті полягає у розкритті психолого-педагогічних механізмів впливу методу проєктів на розвиток пізнавальних інтересів студентів закладів вищої освіти медччного профілю. Автори наголошують, щзо у педагогічній теорії недостатньо з 'ясовано змістові й проичесуальні компоненти реалізації методу проєктів в освітньому прочесі закладів вищої освіти, сприятливі для розвитку пізнавальних інтересів студентів. Автори розкривають сутність актуальності проблеми, оскільки пізнавальні інтереси студентів виступають провідним мотивом навчання і позначаються на результативності ичього процесу. Методологія дослідження базується на наукових концепціях студентоцентричності, цифровізації вищої школи та супроводжується застосуванням емпіричних методів наукового дослідження. Увиразнюється, щуо проєктування у вищій освіті базується на загальноприйнятих визначеннях, принщипах, сформованих етапах діяльності, тісно пов'язане з навколишнім сочіумом та практикою життєдіяльності людини. Вказується на те, що метод проєктів в освітньому процесі дає можливість практичного поєднання і правильного застосування теоретичних знань і чітких практичних навичок, щцо формує здатність злагодженої командної роботи в різних змодельованих ситуаціях та симуляиійних практиках. Авторами визначається, що застосування методу проєктів у процесі розвитку пізнавальних інтересів визначає актуалізацію творчих здібностей, підвищення мотиващії до навчально-пізнавальної діяльності, індивідуальний рівень розвитку усіх учасників проєкту, якість засвоєння базових знань і культури особистості.

Ключові слова: метод проєктів, пізнавальні інтереси, освітній процес, проєктування, продукт праці. 


\section{Nadia HALIUK}

Candidate of Medical Sciences, Associate Professor, Ivano-Frankivsk National Medical University, Halytska str., 2, Ivano-Frankivsk, Ukraine, 76000

ORCID: 0000-0003-2026-0937

\section{Tetiana DIVNYCH}

Candidate of Medical Sciences, Associate Professor, Ivano-Frankivsk National Medical University, Halytska str., 2, Ivano-Frankivsk, Ukraine, 76000

ORCID: 0000-0003-2549-867X

\section{Natalia NISHCHUK}

Assistant, Ivano-Frankivsk National Medical University, Halytska str., 2, Ivano-Frankivsk, Ukraine, 76000

ORCID: 0000-0002-4338-6121

\section{Nataliia TYMOCHKO}

Candidate of Medical Sciences, Associate Professor, Ivano-Frankivsk National Medical University, Halytska str., 2, Ivano-Frankivsk, Ukraine, 76000

ORCID: 0000-0002-5319-5468

To cite this article: Haliuk, N., Divnych, T., Nishchuk, N., Tymochko, N. (2021). Metod proiektiv yak zasib rozvytku piznavalnykh interesiv zdobuvachiv osvity [Project method as a means of developing students' cognitive interests]. Acta Paedagogica Volynienses, 4, 39-44, doi: https://doi.org/10.32782/apv/2021.4.7

\section{PROJECT METHOD AS A MEANS OF DEVELOPING STUDENTS' COGNITIVE INTERESTS}

The purpose of the article is to reveal the psychological and pedagogical mechanisms of influence of the project method for the development of cognitive interests' students of higher educational institutions of medical profile. The authors emphasize that the pedagogical theory does not sufficiently clarify the content and procedural components of the implementation of the method of projects in the educational process of higher education institutions, favorable for the development of cognitive interests of students. The authors reveal the essence of the urgency of the problem, because the cognitive interests of students are the leading motive for learning and affect the effectiveness of this process. The article emphasizes that the leading task of a modern higher education institution is to prepare a fully developed personality, with quality education, with well-formed professional competencies, knowledge, high moral qualities, ability to act independently in various life situations, applying their knowledge and experience. The project method makes it possible to take responsibility for the results of decisions and their own medical practice. The research methodology is based on scientific concepts of student-centeredness, digitalization of higher education and is accompanied by the use of empirical research methods. It is emphasized that design in higher education is based on generally accepted definitions, principles, established stages of activity, closely related to the surrounding society and the practice of human life. It is pointed out that the method of projects in the educational process allows for a practical combination and proper application of theoretical knowledge and clear practical skills, which forms the ability of coordinated teamwork in various simulated situations and simulation practices. The authors determine that the application of the project method in the development of cognitive interests determines the actualization of creative abilities, increasing motivation for learning activities, the individual level of development of all project participants, the quality of basic knowledge and culture.

Key words: project method, cognitive interests, educational process, design, labor product.

Актуальність проблеми. Трансформація системи вищої освіти на засадах педагогіки партнерства, особистісно зорієнтованої педагогіки та студентоцентричності потребує пошуку інноваційного педагогічного інструментарію, оновлених засобів навчання, які розкривають для студентів широкі можливості для розвитку інтелектуальних і творчих здібностей, формують навички критичного мислення.
Передумови для цього закладені в законах України «Про освіту» (2017), «Про вищу освіту» (2017, зі змінами і доповненнями), Національній доктрині розвитку освіти в Україні (2012), де зазначається, що студенти впродовж навчання у закладі вищої освіти (3ВО) повинні здобути не тільки знання та фахові компетентності, але й достатній особистісний досвід культури спілкування і співпраці 
в різних видах діяльності, самовираження у процесі здобуття нових знань та виконанні різнорівневих видів завдань. Саме таким вимогам відповідає метод проєктів як спосіб організації діяльності студентів-медиків, що грунтується на задоволенні їхніх інтересів у безпосередній активності на всіх етапах навчання. Водночас його застосування в освітньому процесі $3 \mathrm{BO}$ медичного профілю має здебільшого ситуативний характер, а використання потенціалу для професійного розвитку пізнавальних інтересів студентів-медиків залишається малодослідженою педагогічною цариною.

У педагогічній теорії також недостатньо увиразнено змістові й процесуальні компоненти реалізації методу проєктів, сприятливі для розвитку пізнавальних інтересів студентів. Звідси випливає актуальність проблеми, оскільки пізнавальні інтереси студентів виступають провідним мотивом навчання і позначаються на результативності цього процесу.

Аналіз останніх досліджень і публікацій. Проблема реалізації методу проєктів в освітньому процесі не $\epsilon$ принципово новою. Вона перебувала у центрі уваги дослідників різних періодів. Так, зокрема, у працях українських і зарубіжних дослідників (3. Бутуєва, Г. Ващенко, І. Єрмаков, Дж. Дьюї, Є. Кагаров, В. Коваленко, Л. Левін, О. Пометун, О. Сухомлинська та інші) розкрито передумови становлення методу проєктів як способу організації навчання, а також відтворено процес його використання у практиці зарубіжної та вітчизняної системи освіти кінця XX - початку XXI ст. Технологію реалізації методу проєктів у системі освіти як форми інноваційної діяльності педагога увиразнено в наукових доробках В. Беспалька, В. Бондаря, Л. Ващенко, Ю. Громика, Л. Даниленко, О. Коберника, Б. Пальчевського, Г. Щедровицького, С. Ящука та інших. Аналіз літератури показав, що в сучасній педагогічній науці метод проєктів розглядають як самостійний метод або ж як цілісну освітню технологію, до якої включено інші творчо зорієнтовані методи.

Мета дослідження - на підставі контентаналізу науково-педагогічної літератури розкрити психолого-педагогічні механізми впливу методу проєктів на розвиток пізнавальних інтересів студентів закладів вищої освіти (ЗВО) медичного профілю.

\section{Виклад основного матеріалу дослідження.} Починаючи з 90-х років XX ст. метод проєктів активно використовується у педагогічній практиці. Він стає об'єктом наукових педагогічних досліджень і вивчається із загально педагогічних позицій (В. Гузеєв, Н. Кисельова, І. Колесникова, М. Морозова та інші) і методичних особливостей застосування (О. Волжина, Л. Масол, Н. Матяш, Є. Полат, В. Симоненко та ін.). Відтак ученими досліджувалися: роль методу проєктів у контексті застосування в освітньому процесі особистісно зорієнтованого навчання (I. Джужук, О. Блохін); формування ключових компетентностей засобами проєктних технологій (Г. Голуб, Н. Пахомова, О. Чуракова); активізація дослідницько-пізнавальної діяльності студентів (О. Гребеннікова, Н. Замошнікова); розвиток творчих здібностей особистості (М. Сердюк, Т. Шевцова). Першу спробу класифікації проєктів зробив наприкінці XIX ст. один із фундаторів впровадження цього методу - В. Кілпатрик (Кілпатрик, 1928). У контексті окресленої проблеми дослідження нам імпонує сучасна класифікація видів проєктної діяльності, проведена дослідницею О. Полат, на засадах провідної ролі діяльності у розвитку пізнавальної активності особистості. Вчена визначає дослідницькі проєкти, творчі проєкти, ігрові проєкти, інформаційні проєкти, практико зорієнтовані проєкти (Полат, 1999).

Проведений контент-аналіз наукових джерел 3 окресленої проблеми показав, що в них здебільшого акцентовано увагу на категоріальному аспекті методу проєктів, а також на способах його застосування в діяльності учнів закладів загальної середньої освіти. Водночас досліджень, де обгрунтовується освітньо-виховний, розвивальний і творчий потенціал методу проєктів, дидактичний аспект його впровадження у практику діяльності ЗВО медичного профілю, є небагато.

Метод проєктів - це сукупність бажаних результатів, ідей, гіпотез для формування творчого теоретичного продукту. Зазвичай під методом проєктів, на думку В. Зайцева, «розуміють сукупність прийомів, дій і процедур у певній послідовності для розв'язання поставленої задачі, особисто значимої для тих, хто навчається, який оформлений у вигляді очікуваного кінцевого продукту» (Зайцев, 2017).

Класифікація видів проєктів відбувається відповідно до таких типологічних характеристик (відповідно до домінуючих видів діяльності): 
1. Провідні методи проєктної діяльності (дослідницький, творчий, рольово-ігровий, ознайомлювально-орієнтувальний).

2. Характер керівництва та координації проєктом.

3. Способи взаємодії між учасниками проєкту.

4. Кількість учасників, задіяних у реалізації проєкту.

5. Термін дії (тривалість) проєкту.

6. Презентація та захист результатів проєктної діяльності.

7. Рефлексія.

7. Аналіз та корекція видів діяльності учасників проєкту.

У різних класифікаційних системах, запропонованих науковцями, перевага надається комплексу ознак, інтеграція яких заклала сталі умови для успішного розв'язання поставлених завдань проєкту. Зазначене підводить до висновків, що типологія проєктів залежить від цілей і завдань навчання.

Завдання сучасного закладу вищої освіти це підготовка всебічно розвиненої особистості, 3 якісною освітою, з добре сформованими професійними компетентностями, яка не лише володіє знаннями, високими моральними якостями, а здатна самостійно діяти в різноманітних життєвих ситуаціях, застосовуючи свої знання і досвід, беручи на себе відповідальність за результати прийнятих рішень та власну медичну практику. Великі можливості у вирішенні цих завдань забезпечує застосування методу навчальних проєктів в освітньому процесі. Адже уміти створювати, реалізувати чи брати участь у проєктах - це вагома життєва компетентність особистості, основи якої можливо оптимально сформувати й розвинути в умовах навчання особистості в закладі вищої освіти медичного профілю.

Проєктування у вищій освіті базується на загальноприйнятих визначеннях, принципах, сформованих етапах діяльності, тісно пов'язане 3 навколишнім соціумом та практикою життєдіяльності людини.

Увиразнивши зазначене, визначаємо проєкт як унікальний комплекс узагальнених процесів, які містять чітко скоординовані й добре керовані завдання $з$ визначеною початковою і кінцевою датою виконання, створених для досягнення окреслених мети та завдань, оскільки реалізації мети і завдань навчального проєкту вимагає отримання результатів, що відповіда- ють визначеним вимогам освітньої діяльності (Коберник, 2002).

Відповідно, проєкт в освітньому процесі ЗВО можна використовувати як інноваційну форму розвитку пізнавальних інтересів студентів, як дієвий варіант самоосвітньої діяльності, як альтернативний спосіб організації роботи студентів на практичних і лабораторних заняттях, як дієвий спосіб інтеграції в європейську систему освіти. Метод проєктів є досить успішним у процесі розвитку наукових і пізнавальних інтересів студентів, оскільки він дає можливість ефективно використовувати педагогічний інструментарій викладача, творчий потенціал студента, сприяє інтеграції їхніх знань, мотивує до активізації самостійної навчально-пізнавальної діяльності.

Застосування методу проєктів в освітньому процесі значно підвищує зацікавленість студентів у здобутті знань, підвищує якість освіти і продуктивність навчання, що підтверджується результатами проміжного та підсумкового контролю знань студентів. Метод проєктів дає можливість одночасно навчати студентів правильно використовувати свої знання і діяти в різних ситуаціях, що моделюються під час реалізації дослідницьких, творчих чи практичних проєктів.

У багатьох країнах Європи метод проєктів визнано одним із найефективніших методів навчання. Тому вивчення позитивного досвіду та його адаптація до реалій української системи вищої освіти $є$ одним із завдань професорськовикладацького складу. Залучення студентів до проєктної діяльності особливо ефективне у процесі роботи над вивченням спеціальних дисциплін.

Сучасна система вищої освіти зорієнтована на пошук і застосування в освітньому процесі інноваційних форм, методів і технологій організації навчання, які сприятимуть активізації навчально-пізнавальної діяльності студентів як майбутніх фахівців у медичній сфері. У цьому контексті все більше уваги зосереджується на засобах розвитку творчого потенціалу особистості, виробленні професійно зорієнтованих навичок практичної діяльності та формуванні фахової компетентності. Метод проєктів по праву виступає одним із затребуваних і пріоритетних методів професійної вищої медичної освіти, застосування якого сприятиме розвитку пізнавальних інтересів студентів. Проєктна діяльність успішно застосовується в освітньому 
процесі і вдало поєднується з різними видами учбової та дослідницько-пошукової роботи студентів. Психолого-педагогічними умовами організації проєктної діяльності студентівмедиків є з'ясування заздалегідь вироблених, сформованих уявлень про кінцевий продукт освітньої діяльності, визначення мети, завдань та візії проєктної діяльності; окреслення етапів проєктування (створення концепції і плану проєкту), підбір оптимальних ресурсів; визначення видів роботи (колективна, індивідуальна, змішана) над проєктом; визначення очікуваних результатів, рефлексія, аналіз та контроль; корекція (за потреби) отриманих результатів.

Застосування методу проєктів під час навчальних занять сприяє розвитку критичного мислення студентів, формує здатність самостійно визначати траєкторію науководослідної діяльності та пошуку оптимальних засобів здобуття та аналізу джерел інформації, використовувати емпіричні та практико зорієнтовані методи для вирішення пізнавальних i практичних задач. Окрім цього, оптимальне застосування методу проєктів в освітньому процесі, особливо під час проведення практичних та лабораторних занять, сприяе збагаченню мовлення, розвитку лідерських позицій та комунікативних навичок.

Таким чином, практика застосування методу проєктів як різновиду науково-орієнтованого навчання в медичній освіті доводить результативність його застосування. Метод проєктів можна рекомендувати як новітній інструмент, застосування якого на практичних i лабораторних заняттях сприяє розвитку критичного мислення професійно зорієнтованої особистості студента і як додатковий високо ефективний та дієвий стимул пізнавальної діяльності. Оскільки розвиток медичної освіти передбачає тріумвірат клінічної практики, медичної освіти і науково-проєктної діяльності, то введення до освітнього процесу сучасних проєктних методів дозволить краще розвивати та вдосконалювати навички студентів під час вивчення базової термінології, вироблення сталих алгоритмів дій під час виконання практичних завдань 3 клінічної практики, навчить працювати в команді, сприятиме кращому обміну знаннями та їх застосування під час прийняття правильного рішення (виконання практичних завдань у лабораторіях симуляції). Для активізації пізнаваль- ної діяльності студентів необхідно розробити окремі алгоритми проведення практичних i лабораторних занять 3 чітким інформаційнодидактичним супроводом та розробленими методиками інтерактивного навчання студентів. Це можуть бути: «дерево рішень», презентація, відеосюжети, вікторина, практичне моделювання, бліц-опитування, онлайн-тестування, дискусійні площадки, ігрові ситуації тощо. Вибір тематичної спрямованості студентських проєктів відбувається 3 метою вдосконалення теоретичних знань, розвитку пізнавальних інтересів, має чітку практико зорієнтовану мету та призначення. За умов проєктної роботи викладач виступає як модератор освітньої діяльності студентів та як мотиватор їхнього особистісного розвитку і професійного зростання (як старший, досвідчений колега, як успішний фахівець, як приклад).

Метод проєктів в освітньому процесі дає можливість практичного поєднання правильного застосування теоретичних знань і чітких практичних навичок, що формує здатність злагодженої командної роботи в різних змодельованих ситуаціях та симуляційних практиках. Здобуті таким чином фахові компетентності $\epsilon$ надзвичайно важливими для майбутньої професійної діяльності. Адже участь студентів у вирішенні підготовлених завдань, практичних задач дає можливість розвивати інтелектуальні здібності, сприяє розширенню мотивації до якісного виконання завдань, вибору оптимальних варіантів вирішення окреслених задач проєкту, формує зацікавленість кожного студента у високому результаті виконаної роботи, сформованості «колективного продукту праці». Отриманий якісний результат колективної роботи мотивує студентів до подальшої активної роботи на заняттях та якісного виконання самостійних та дослідницько-пошукових завдань. Проєктна діяльність дає можливість студентам працювати як у команді (під час виконання великих за обсягом командних проєктів), так й індивідуально (під час роботи у лабораторіях симуляції). Під час роботи над проєктом студенти самостійно обирають відповідні сюжетно-рольові ігри, комунікативно-орієнтовані вправи, самостійно складають типові завдання, моделюють інші проєкти, готують їх презентацію, захист та продумують шляхи подальшої реалізації. Дослідження останніх 
років $з$ окресленої проблеми, на думку В. Зайцева, «підтверджують серйозні якісні зміни у навчанні студентів вищої школи проєктним технологіям. Визначився перехід від технократичної до інтегративної інноваційної проєктнотворчої моделі навчання, а відповідно, до нової якості освіти» (Зайцев, 2017).

Узагальнення визначень методу проєктів сучасними дослідниками (О. Александрова, В. Гузеєва, О. Полат, І. Чечіль та інші) дає підстави стверджувати, що метод проєктів - це дієвий спосіб стимулювання зацікавленості студентів певними освітніми проблемами чи досвідом практичної діяльності, що передбачає оволодіння базовими знаннями та практичними навичками крізь призму здобутого досвіду проєктної діяльності.

Висновки i перспективи подальших досліджень. У науковій і методичній літературі досить широко і різнобічно розкрито сутність понять «метод проєктів», «проєктна діяль- ність». У нашому дослідженні ми акцентуємо увагу на сутності методу проєкту як інноваційної форми організації освітньої діяльності та розвитку пізнавальних інтересів здобувачів освіти. Нові освітні технології якісно змінюють стиль, характер, зміст вищої освіти, розвивають у студентів самостійність, сприяють формуванню здатності до самоорганізації, вмінню вести діалог, відстоювати свою позицію, з повагою ставитися до думок інших учасників проєктної діяльності. Таким чином, застосування методу проєктів у процесі розвитку пізнавальних інтересів визначає актуалізацію творчих здібностей, підвищення мотивації до навчально-пізнавальної діяльності, індивідуальний рівень розвитку усіх учасників проєкту, якість засвоєння базових знань і культури особистості. Перспективи подальших наукових розвідок пов'язуємо 3 проблемою розробки інноваційних проєктних технологій у контексті вимог цифровізації вищої освіти.

\section{ЛITEPATУРА:}

1. Зайцев В.С. (2017). Метод проектов как современная технология обучения: историко-педагогический анализ. Вестник Челябинского государственного педагогического университета. № 6. С. 52-62.

2. Килпатрик В.Х. (1928). Основы метода. Москва : Госиздат, 115 с.

3. Коберник О.М. (2002). Розвиток методу проектів у вітчизняній і зарубіжній педагогічній теорії і практиці: зб. наук. пращь УДПУ : Спецвипуск. Київ : Науковий світ. С. 127-130.

4. П’ятакова Г.П. (2003). Сучасні педагогічні технології та методика їх застосування у вищій школі Львів : Вид. центр ЛНУ ім. І. Франка, 55 с.

5. Підласий І.П. (2004). Практична педагогіка або три технології. Київ : Слово, 616 с.

6. Полат Е.С. (1999). Новые педагогические и информационные технологии в системе образования: монография. Москва : Академия, 272 с.

\section{REFERENCES:}

1. Zajcev V. S. (2017). Metod proektov kak sovremennaya texnology'ya obucheny`ya: y`story 'ko-pedagogy`chesky`j analy'z [Project method as a modern learning technology: historical and pedagogical analysis]. Vestny'k Chelyabynskogo gosudarstvennogo pedagogy'cheskogo unyversy'teta, no. 6, pp. 52-62. Retrieved from: URL: https://cyberleninka.ru/article/n/metod-proektov-kak-sovremennaya-tehnologiya-obucheniya-istoriko-pedagogicheskiyanaliz(accessed (10.07.2021)) (in Russian).

2. Kylpatryk V. X. (1928). Osnovi metoda. [Fundamentals of the method]. Moskva : Gosyzdat, 115 p. (in Russian)

3. Kobernyk O. M. (2002). Rozvy`tok metodu proektiv u vitchy`znyanij i zarubizhnij pedagogichnij teoriyi i prakty`ci [Development of the project method in domestic and foreign pedagogical theory and practice] : zb. nauk. pracz 'UDPU: Speczvy pusk. Ky`yiv : Naukovy`j svit, pp. 127-130. (in Ukraine)

4. P'yatakova G. P. (2003). Suchasni pedagogichni texnologiyi ta metody'ka yix zastosuvannya u vy`shhij shkoli L`viv : Vyd. centr LNU im. I. Franka, 55 p. (in Ukraine)

5. Pidlasy’j I. P. (2004). Prakty'chna pedagogika abo try' texnologiyi [Practical pedagogy or three technologies]. Ky'yiv : Slovo, 616 p. (in Ukraine)

6. Polat E. S. (1999). Novie pedagogycheskye y' y'nformacy`onnie texnology'y' v sy`steme obrazovanyya: monografy'ya. [New pedagogical and information technologies in the education system: monograph.] Moskva: Akademyya, 272 p. (in Russian) 